\title{
Zpráva z konference doktorandů PedF UK
}

V rámci Úvodního teoreticko-metodologického kurzu pedagogiky (ÚTMKP) se 21. května 2012 uskutečnil 8. ročník doktorandské konference, kterou již tradičně pořádá Ústav výzkumu a rozvoje vzdělání Pedagogické fakulty Univerzity Karlovy v Praze (ÚVRV).

Reflexe kvality vzdělávání v doktorandském pedagogickém výzkumu bylo stanovené téma konference, nad kterou převzala záštitu děkanka Pedagogické fakulty doc. PaedDr. Radka Wildová, CSc. Z doktorandů, pro které je kurz pedagogiky povinným článkem studia, byl sestaven organizační výbor konference. Předsedkyní organizačního výboru byla zvolena PhDr. Petra Koukalová.

Úvodní řeč přednesla děkanka pedagogické fakulty doc. PaeDr. Radka Wildová, CSc., která vyjádřila podporu způsobu konání doktorandských konferencí. Všem prezentujícím popřála úspěch také garantka kurzu doc. PaedDr. Jaroslava Vašutová, Ph.D., která také vyzdvihla jeho význam pro další odbornou práci doktorandů.

Úvodní dva referáty v plénu přednesli dva hosté, kteři přijali pozvání na konferenci. Jako první přednesla svůj referát prof. PhDr. Vladimíra Spilková, CSc. na téma Kompetence pro 21. století - vývoj pohledů na cíle vzdělávání. Obsah referátu se zabýval evropskými trendy v prístupech k formulování kvality učitele. Charakterizoval klíčové prvky profesionální kvality učitele a nastínil hledání východiska pro profesní standard učitele. Druhým hostem byla RNDr. Jana Straková, Ph.D., která přednesla referát na téma Kvalita učitele a její hodnocení. Referát analyzoval vymezení kompetencí pro 21. století a pokusil se navrhnout způsoby jejich hodnocení.

Po úvodním setkání se konference rozdělila do dvou sekcí - sekce pedagogické a sekce lingvodidaktické. Každé sekce se zúčastnili dva odborní garanti, kteří reflektovali př́spěvky doktorandů.

Garanty pedagogické sekce byli doc. PaedDr. Jaroslava Vašutová, Ph.D. a doc. PaedDr. Petr Urbánek, Dr. Moderátorem jednání se stala Mgr. Monika Schmidtová. Oba dva bloky pedagogické sekce byly pestré a nabídly pohled na mnoho zajímavých odborných témat.

V prvním příspěvku informoval PhDr. Bohuslav Dvořák o výzkumu kvality vzdělávání mezi účastníky programu rozšiřujícího studia v oboru anglický jazyk a literatura na Katedře anglického jazyka a literatury Pedagogické fakulty UK v Praze. Druhý příspěvek přednesla Mgr. Jana Havlíčková, která se s přítomnými podělila o své zkušenosti s využitím různých vyučovacích metod na střední škole v Zambii, kde nějaký čas 
pobývala. Následující příspěvek se týkal výživových zvyklostí žáků v základní škole. Přednesla jej Mgr. Jana Koptíková. Zveřejněné údaje byly založeny na výzkumu uskutečněném $v$ ZŠ v Přešticích a pro mnohé představovaly překvapivá a neočekávaná zjištění. Závěrečný přispěvek $v$ dopoledním jednání sekce přednesl PhDr. Josef Levý. Zabýval se problematikou začleňování regionálního zřetele do předmětů o prírodě a společnosti na 1. stupni ZŠ. Odborný výklad byl opřen o osobní praktické zkušenosti učitele na primární škole. První vystoupení v odpolední části jednání sekce patřilo Mgr. Jolaně Ronkové. Týkalo se kvality edukace $v$ oblasti čtenářské gramotnosti v primární škole. Mgr. Ronková prezentovala výsledky výzkumu a přitom ukázala, jak nedostatky $v$ překladu textů, na nichž je výzkum založen, mohou tento výzkum ovlivnit. Jako druhý vystoupil PhDr. Radim Štěrba, jehož vystoupení se týkalo především zahraničních i domácích teoretických zdrojů a východisek k tématu empatie jako součást sociální kompetence učitele. Předposlední vystoupení obsáhlo téma role a možností využití pojmových map v edukačním procesu. $S$ tímto př́spěvkem vystoupila Mgr. Petra Vaňková. Jako poslední přednesla svůj př́spěvek moderátorka sekce Mgr. Monika Schmidtová. Představila svůj výzkum, jehož cílem je zjistit, jak studenti několika fakult ČVUT pohližejí na společenské vědy.

Garanty lingvodidaktické sekce byli PhDr. Martin Chvál, Ph.D. a PhDr. Karel Starý, Ph.D. Moderování se zhostil Mgr. Jakub Konečný. Také lingvodidaktická sekce nabídla širokou škálu zajímavých námětů, které mnohé účastníky zaujaly. Sekce byla ve znamení cizích jazyků, nejpočetnější zastoupení měl francouzský jazyk, objevil se i ruský a německý jazyk, kterým dopolední část sekce začala.

První příspěvek byl věnován tématu interaktivní tabule. Referující Mgr. Zdeňka Španingerová ukázala konkrétní príklady práce se slovní zásobou v německém jazyce prostřednictvím interaktivní tabule, prezentovala také didaktické využití interaktivní tabule pro zkvalitnění výuky. Srovnáním př́stupů $k$ literatuře $v$ ČR a ve Francii se ve svém příspěvku zabýval Mgr. Daniel Hanšpach. Uvedeným příspěvkem odstartovala francouzská sekce, kterou podpořila Mgr. Jana Prokešová. Její téma Jazykové sekce - integrované vzdělávání ve francouzském jazyce zahrnovalo podoby cizojazyčné výuky CLIL a bilingvní výuku. Zmíněn byl plán Komise Evropské unie „Podpora jazykového vzdělávání a jazykové rozmanitosti“ a „Národní plán výuky cizích jazykư“. Hodnocení a typy hodnocení zahrnoval příspěvek Mgr. Sylvie Vondrákové. Příspěvek byl zaměřen na francouzský jazyk a popisoval výzkum provedený na francouzských školách, např. jaké způsoby evaluace učitelé v praxi použivají a zda při hodnocení zohledňují Společný evropský referenční rámec. Poslední prezentací, uzavírající sekci francouzského jazyka, bylo téma Mgr. Elišky Navrátilové. Zmíněny byly aspekty ovlivňující osvojování výslovnosti, především věk. Limity související s věkem (neurologické změny, sociálně-psychologické limity, percepční návyky apod.). Tematikou výslovnosti se zabýval i Mgr. Jakub Konečný, tentokrát na príkladu výuky ruského jazyka. Poukázal na to, jakým způsobem jsou zpracována cvičení na výslovnost v učebnicích Raduga po-novomu a Pojechali. Zjišt’oval, zda jsou otázky komunikativně zaměřeny. PhDr. Petra Koukalová přednesla příspěvek o CLIL v evropském výzkumu. $\vee$ prríspěvku byl vysvětlen pojem CLIL, dualita CLILu (cizí 
jazyk a odborný předmět), výstupy, komunikace ve vyučování a implementace CLILu do škol. PhDr. Marta Kvíčalová srovnávala přezdívky ve skautském a ve školním prostředí. Její téma popisovalo, jak přezdívky vznikají (deformací z křestního jména, z př́ijmení většinou ve školách, díky charakteristickým rysům, fyzickým dispozicím a zájmům spíše ve skautském prostředí).

Celkem bylo v obou sekcích předneseno 16 referátů. Po každém vystoupení podali uvedení moderátoři sekce zpětnou vazbu, která pro prezentující představovala cenné připomínky a podněty. Byl vyhrazen čas pro diskusi, která byla spiše váhavá, nicméně daný čas poskytl přítomným prostor pro dotazy, názory a upřesnění prípadných nejasností.

$\mathrm{Na}$ závěrečném jednání $v$ plénu vystoupili moderátoři obou sekcí, kteří seznámili př́tomné s obsahem a výsledky jednotlivých sekcí. Závěrečné slovo přednesla doc. PaedDr. Jaroslava Vašutová, Ph.D. V něm shrnula průběh konference, upozornila na klady, ale i na př́padné nedostatky a rezervy referátů a popřála doktorandům hodně úspěchů $v$ jejich odborném životě. Organizační výbor ukončil jednání poděkováním garantce kurzu, všem lektorům a zúčastněným.

Celý kurz byl doktorandy ohodnocen pozitivně. Konference byla zhodnocena jako úspěšné zakončení prvního roku studia. Konference byla přijata doktorandy jako dobrá zkušenost a možnost, jak vstoupit do vědeckého výzkumu. $V$ neposlední ŕadě byl oceněn fakt, že si každý mohl vyzkoušet, jak se vystupuje před kolegy, jak dokáže reagovat na věcnou kritiku a jak se dokáže na vědeckou konferenci připravit.

Více informací o vědecké konferenci lze nalézt na internetových stránkách: http://kraken.pedf.cuni.cz/konference12/index.html.

PhDr. Josef Levý levjos@post.cz 